\title{
Discretionary loan loss provision in the Moroccan banking sector: The role of governance mechanisms
}

Yousra El Mokrani ${ }^{1 *}$, Issam El Idrissi ${ }^{2}$, Youssef Alami ${ }^{3}$

Laboratory of Finance, Audit and Management Research, LAREFAG, ENCG, Abdelmalek Essaadi University, Tetouan, Morocco ${ }^{1,2,3}$

yousra.mokraniel@gmail.com ${ }^{1 *}$, issammpd115@gmail.com ${ }^{2}$, y.alami@uae.ac.ma ${ }^{3}$

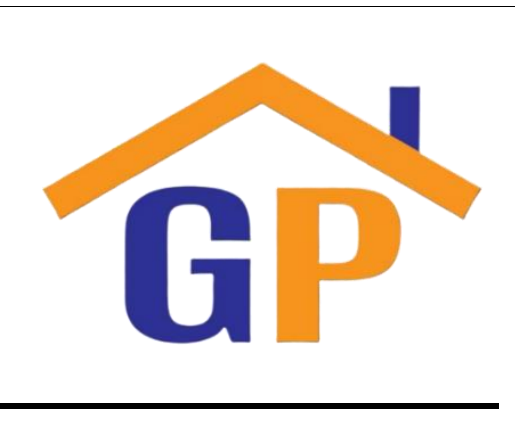

Article History

Received on 19 October 2021

$1^{\text {st }}$ Revision on 17 November 2021

$2^{\text {nd }}$ Revision on 26 November 2021

Accepted on 1 December 2021

Abstract

Purpose: The present paper aims to examine the impact of corporate governance mechanisms on earnings management extent in the Moroccan banking sector.

Research methodology: This research investigates the relationship between listed banks' governance mechanisms and earnings management in the CSE over the period 2017-2020. This study relies on a two-step quantitative approach, which consists firstly of estimating discretionary loan loss provisions to measure EM, then presenting the association between banks' governance mechanisms and discretionary loan loss provisions.

Results: The findings indicate that board size, gender diversity, audit committee's independence, and state ownership constraint EM practices among the Moroccan listed banks. While other governance mechanisms, such as institutional ownership and board activity, seem to have no significant effect on restraining managers' discretionary behavior.

Limitations: Many qualitative and quantitative factors could influence discretionary loan loss provisions and not only the used variables in this research.

Contribution: This research reveals the need to maintain the vigilant supervision of the regulatory framework to limit these opportunistic practices in the local banking industry. Also, our study has important implications for establishing a new set of governance requirements such as board diversity in Morocco.

Keywords: Board of directors, Earnings management, Governance mechanisms, Loan loss provisions, Moroccan Banks

How to cite: Mokrani, Y, E., Idrissi, I, E., \& Alami, Y. (2021). Discretionary loan loss provision in the Moroccan banking sector: The role of governance mechanisms. Annals of Management and Organization Research, 2(3), 191-208.

\section{Introduction}

The importance of reported earnings in the market has grown significantly over the last decade. A bank's stock price can drop several points if its earnings per share do not match the analysts' forecasts. Accordingly, over the last few decades, several researchers concluded that firms occasionally strive to smooth or manipulate their published earnings (Menicucci, 2020). The historical evidence on earnings management (EM) appearance was stated by Cohen et al., (2004) when they mentioned that EM practices began to spread constantly around 1997 and peaking in 2002.

Moreover, EM can be achieved in various ways, including using the accounting standards' discretion, changing the firm's depreciation policy, including depreciation methods and estimates, and adjusting the estimate of non-performing debt provisions for the baking industry. Generally, among numerous purposes, EM is practiced only for two (Makhaiel \& Sherer, 2017), either to hide the real financial performance for misleading purposes or to convey private information for signaling purposes. 
On a regional scale, the Moroccan banking sector is distinguished by its performance. This rigor comes from the central bank's vigilant supervision. Additionally, in recent years, the banking regulatory framework has significantly improved to cover more areas, such as governance and CSR. Given these improvements, Moroccan banks are increasingly pushed to operate with high efficiency. However, the non-performing loans (NPL) ratio and loan loss provisions do not stop worrying the local financial authorities, especially after the Covid-19 crisis (BKAM, 2020), because these ratios are considered as an accurate measurement for banking risks (Endri, Marlina, \& Hurriyaturrohman, 2020). Similarly, Salem, Labidi \& Mansou (2020) state that an increasing NPL ratio creates a variety of risks to a bank's financial viability. Meanwhile, the IMF (2019) attests that our banking system's provisioning levels are comfortable (69 percent in the last three years).

In this context, our study examines EM in listed commercial banks in Morocco and mainly how corporate governance mechanisms affect EM. Thus, we aim to explore the role of corporate governance guidelines in constraining EM practices in the Moroccan banking industry.

The study relied upon panel data analysis spanning the period from 2017 to 2020 . The regression analysis was based on the GMM EGLS technique. Regarding the data sources, the information used to conduct the current research was manually collected from banks' financial statements and reports.

The results found in this paper point out the strength of the board's size, gender diversity, audit committee's independence, and state ownership in restraining EM practices, which were presented in this study by the discretionary loan loss provision's absolute value.

The paper is organized as follows. In the Literature review section, we present the regulatory framework of corporate governance in the Moroccan banking industry. Also, we discuss the theoretical foundation of EM in the banking sector. Next, we develop our theoretical model and hypotheses. We then describe our research methodology before estimating EM accruals using the DLLP approach. The last section concludes with a presentation of our regression results and a summary of our findings.

\section{Literature review}

\section{Corporate governance in the Moroccan banking sector}

In Morocco, corporate governance in the banking sector works within the limits of the framework set by Law No. 17-95 as amended and supplemented by Law No. 20-19, Law No. 20-05, Law No. 103-12 relating to credit institutions and similar organizations (i.e., banking Law), the bank's statutes and the central bank's recommendations.

The Moroccan Code of Good Corporate Governance Practices of 2008 prefers and supports the dual structure to limit the CEOs' power. The ultimate goal of this reasoning is to provide an opportunity for the bank to separate its process of developing a long-term strategy from operational bank management, which can give a clear, well-defined, and independent view on business administration. This does not imply that the strategy development process is separated from operational management results.

According to the second article of Bank Al-Maghrib Circular No. 1/W/2014 on governance within credit institutions, the missions of the governance body may arise in the definition of all aspects related to the risk policies adopted by the management board, monitoring the control system's activities and results at least once a year, the elaboration of an incentive compensation policy, and other missions.

In Morocco, the regulatory framework's minimal limit of board meetings is one meeting per year. A simple analysis of the data we have collected shows that our sample banks meet at least five times a year. Furthermore, our sample's highest number of board members is fourteen, with a minimum of nine members from 2017 to 2020, which is aligned with the maximal limit of fifteen members fixed by the corporate governance law.

Following article 20 of Law No. 17-95, the appointment of board members is assured by the Ordinary General Meeting of shareholders. In this way, the first directors are nominated by the default corporation rules or in a separate act forming the previous law rules. In case of death or resignation of a former member, article 49 of Law No. 17-95 authorizes the board to appoint a new director. Regarding 
managers' remunerations, banking regulation does not impose broadcasting the board members' paychecks and can be under token fees, exceptional wages, etc.

In general, and according to the sixth article of Bank Al-Maghrib circular No. 1/W/2014 relating to the governance within credit institutions, a manager is qualified as independent when he maintains no relation with the bank, its group, or its board, which can compromise his freedom of judgment. Moreover, circular No. 5/W/2016 of Bank Al-Maghrib indicates that an independent member within a bank's board must have competencies and experiences in banking risk management, internal control, and governance.

\section{EM in the banking sector}

International reporting standards enhance the accounting systems of all companies worldwide. However, like any other regulation system, these standards allow managers to manipulate revenues and costs to change earnings or accomplish other plans. Also, academic research on this particular topic of earnings management has received considerable attention in recent years, especially after the financial crises of the 2000s. For Schipper (1989), managerial intentions to manipulate the financial reporting process are driven by pursuing private gains. Generally, earnings management practices are used for three purposes, income smoothing, signaling, and capital management. In other words, earnings management practices help managers reduce the net income changes through a financial year, signal private future financial information about future earnings levels to specific investors, and raise the capital ratio to comply with local and international standards. Ceccobelli \& Gliosi (2019) concluded that income smoothing is a practice well used in the banking industry in order to reduce the reported income changes' variance by choosing specific accruals.

Another managerial breadth is to signal sensitive information to private investors on future earnings using the Loan Loss Provisions (LLP), insofar as an increase in LLP's volume can be interpreted by investors as promising signs for development and not as a deterioration in the bank's credit portfolio as suggested by Curcio \& Hasan (2015). In addition, Ozili \& Outa (2017) confirmed that abnormal LLP estimates could be considered to signal private information about a bank's non-performing loans.

Ben Othman \& Mersni (2014) acknowledged that LLP practices are the most used to manipulate banks' earnings. According to Taktak \& Mbarki (2014), bank managers often employ specific accruals to communicate the information that best serves their objectives. In fact, Zgarni \& Fedhila (2019) announced that accounting standardization, external financing, and the bank's economic visibility are the most influencing factors on LLP in banks. However, two incentives for earnings management have been empirically detected by Ben Othman \& Mersni (2014), Mersni \& Ben Othman (2016), and Taktak \& Mbarki (2014), are the level of earnings and the level of regulatory bank capital. Indeed, Cornett, McNutt, \& Tehranian (2006) concluded that bank executives seem to employ discretionary provisions to boost the bank's incomes and, as a result, their own personal wealth. Thus, several studies have confirmed the positive relationship between LLP and bank earnings (Andries, Gallemore, \& Jacob, 2017; Saurina, 2009).

For instance, in a review, Ozili \& Outa (2017) confirmed that most research on LLP practices in the MENA region is about comparing Islamic banks to conventional banks. However, earnings manipulation in the banking industry is costlier than in other industries because of the banking system's vital role in promoting economic development on a national scale (Al Hajjar, Mokhtar, \& Mandour, 2021).

Earlier research on 900 observations during 1980-1984 by Ma (1988) proved that US banks engaged in EM through provisioning policy. In the same year, Greenawalt \& Sinkey (1988) confirmed that US banks use LLP to smooth their incomes. Also, Lobo \& Yang (2001) found strong evidence indicating the use of discretionary LLP for income smoothing, signaling, and capital management by US banks between 1981-1996. Similarly, Taktak, Shabou, \& Dumontier (2010) have detected the same practices by studying 278 banks operating in the OECD region. Therefore, there is a need for more control and supervision by governance bodies to limit this type of manipulation. 


\section{Corporate governance and earnings management}

In this current section, we will present our conceptual model. It is noteworthy that a bank's governance system monitors EM because of the banks' direct connection with the national, regional, and global economy. Moreover, solid banking management enhances the bank's market value (Sugianto, Oemar, Hakim, \& Endri 2020). Prior research indicates that internal governance processes are more successful in the banking industry than external ones (Mersni \& Ben Othman, 2016). Indeed, the inherent characteristics of banks, such as the intricacy of agency issues and the presence of information asymmetry between outsiders and insiders, and the role of regulation, erode the disciplinary effect of external mechanisms. For example, the board of directors is considered to be the critical factor of any governance system in any corporation, and even the reporting system depends on all the information provided by this governance body. Also, internal mechanisms limit the managers' discretionary behaviors according to the agency theory (Priharta, Rahayu, Marlapa, \& Endri 2020). Thus, we will focus in this study on the effectiveness of internal corporate governance mechanisms, especially the board of directors and audit committee, besides the ownership structure.

\section{Board of directors}

Literature review asserts that the board of directors is the most efficient dispositive to supervise and control managers. However, earlier studies asserted that the board size could influence the monitoring process of a bank manager, while other academic research concluded that there is a negative association between board size and managers' opportunistic behaviors. Therefore, the board's size could be an essential variable to ensure the effectiveness of the corporate governance system, especially in the banking industry where the regulatory framework and the macroprudential supervision are present. Indeed, Levine (2004) highlighted the three factors making the banking governance more special than firms. To begin, banks' opaqueness amplifies information asymmetry and makes incentive arrangements that match managers' interests with those of banks' equity holders more challenging to create. Second, increased informational asymmetries obstruct the efforts of dispersed equity and debt investors to supervise bank executives effectively. Third, legal limitations on bank ownership concentration prevent outsiders from acquiring a significant proportion of bank shares and exercising governance as concentrated shareholders. Finally, the existence of a deposit insurance system lowers depositors' incentives to supervise banks effectively and encourages banks to operate with a high degree of leverage, which increases the bank's risk exposure. Thus, the importance of the governing body arises under these circumstances.

Vasilakopoulos, Tzovas, \& Ballas (2018) state that the board of directors' oversight role may have specific consequences on managers' accounting discretion. Accounting statistics is a critical source of information for a board's decision-making. As a result, the board of directors will need comparable and verifiable financial data in order to make decisions and supervise management. Therefore, managers who are aware that their accounting discretion is being carefully scrutinized will abstain from manipulating financial statements.

\section{Board size}

According to the agency theory, a large board fosters conflicts of interest between the management and shareholders, mostly due to coordination and communication problems that may impede consensus decision-making (Jensen, 1993). This situation is the most opportunistic to managers willing to use their discretionary behaviors to maximize their wealth by using EM techniques, especially when they dominate other board members by numbers (Lipton \& Lorsch, 1992). However, the resource dependency theory contradicts the size restrictions made by the agent-principal theory because a large board of directors acquires the necessary competencies broth by the different administrators. Therefore, the more a board's size amplifies, the more the governance system's overall quality of monitoring and supervising enhances.

Klein (2002) announce that firms with large boards are more effective in detecting financial reporting irregularities. However, Farag \& Mallin (2019) state that a large board size is required to monitor the supervisory board in the Germanic governance structure and to supervise complex operations such as in the banking sector. Therefore, despite the mixed findings in the literature between those who found 
a negative association (Jamaludin, Sanusi, \& Kamaluddin, 2015; Xie, Davidson, \& DaDalt, 2003; Ghosh, Marra, \& Moon, 2010) or no association at all (Osemene, Adeyele, \& Adinnu, 2018; Elghuweel et al., 2017), we are going to state the following hypothesis:

Hypothesis 1. Board size negatively affects EM in the Moroccan banking sector.

CEO's duality

The dualist governance structure helps to clear the roles between those of the CEO and the chairperson of the board of directors. However, the classic composition stands for directly nominating the CEO as the board's chairman. For Tricker (1994), CEO duality reduces the board's independence. Also, Bradbury, Mak, \& Tan (2006) indicate that splitting the two functions is not a strategic decision to enhance performance because CEO duality reduces the rivalry and enhances the business's clarity.

According to Al Hajjar et al., (2021), there are two streams in the relationship between CEO duality and EM, either negative or positive. However, the literature review reveals that empirical evidence on the interplay between CEO duality and EM is not well treated in emerging countries like Morocco. For example, in Tunisian banks, Omri \& Ajlani (2008) confirmed that the duality of the board's president increases earnings management under the significant presence of institutional directors. Likewise, Nuanpradit (2019) and Ge \& Kim (2014) found a significatively positive relation between real earnings management and CEO duality. Additionally, Dalton (2012) and Dahya, Garcia, \& van Bommel (2009) suggest that duality is critical for establishing centralization of power and organizational unity in order to minimize possible conflict between the CEO and chairman. In contradiction to the stewardship theory's point of view, we anticipate that duality reduces the board's dynamic functioning. In this case, the sign of this variable is expected to be positive:

Hypothesis 2. CEO duality positively affects EM in the Moroccan banking sector.

Directors' independence

Enhancing the board's monitoring abilities requires nominating independent directors in accordance with most of the good corporate governance codes. In Morocco, the capital market authority forces listed companies to recruit at least one independent director. In general, independence is associated with firm performance, especially in banks. Anderloni, Moro, \& Tanda (2020) confirmed that the independence level of directors is considered the most influencing factor on board's effectiveness after the board's size. Fama \& Jensen (1983) confirmed that the independence of directors could reduce the collusion problems with top management. Therefore, their presence helps mitigate agency problems and indirectly enhances the organization's performance and its transparency. Moreover, most cited papers in this field found a negative association between board members' independence and EM (Klein, 2002; Xie et al., 2003; Niu, 2006).

Hoping to find a negative association between the directors' independence and EM and based on the above discussion, we formulate the following hypothesis:

Hypothesis 3. Board's independence negatively affects EM in the Moroccan banking sector.

Gender diversity

Empirical studies suggest that women's presence in board composition improves earnings quality because of their monitoring abilities. The theoretical perspectives of several constructs like the agency, economic, behavioral, governance, and other theories suggest that boards without female directors are more likely to face sub-optimal decision-making, which will be a severe source of value destruction (Nguyen, Ntim, \& Malagila, 2020). Recent empirical evidence highlights the existence of a U-shaped relationship between gender diversity and EM (Strydom, Au Yong, \& Rankin, 2017). Also, Fan, Jiang, Zhang, \& Zhou (2019) confirmed the existence of this type of interplay between women's integration on corporate governance and bank EM. Whereas the tokenism phenomenon is less present in the Moroccan banking sector, female managers and executives are well experienced in the financial industry with an extensive accounting and financial consulting background. According to Musah \& Adutwumwaa (2020), female directors' presence will benefit minority groups and promote the oversight of managers. 
Since female directors are directly implicated in the board's monitoring mechanism, a wave of research showed a significant favorable influence of their presence on EM levels and earnings quality among a large set of firms (Srinidhi, Gul, \& Tsui 2011; Boussaid, Hamza, \& Sougne, 2015; Panzer \& Müller, 2015). Therefore, we expect fewer EM practices due to this type of administrators' presence.

Hypothesis 4. Gender diversity reduces EM in the Moroccan banking sector.

Board activity

The board's effectiveness can not only be measured by its size and independence but also the meetings' frequency is an essential variable for performance measurement. In this vein, García Lara, García Osma, \& Penalva (2009) suggested that the frequency of board activities is an adequate proxy for directors' monitoring effort during a fiscal year. The governance body meets to review financial statements and audit reports to communicate the financial situation to shareholders. This critical role should pass in a good business environment to ensure the excellent monitoring activities of different administrators. Noteworthy, the length of some reunions passes in routine protocols, such as nominating new directors, discussing the semestrial financial reports, signing documents, and evaluating the board's performance. Moreover, Al-Musali \& Ku Ismail (2015) indicated that the lack of time to finish the board duties weaknesses the quality of meetings and, therefore, the global performance rate of the governance body. Generally, the board seeks to enhance the reliability of all financial statements (Vafeas, 1999). Similarly, Xie et al., (2003) indicate that board meetings are treated as signals for board performance and effectiveness. Also, the same authors claim that high board meetings frequency helps to deal with EM issues. Contrary to Jensen (1993) and Vafeas (1999), who found no significant link between meetings' frequency and board performance because of time absorption in regular duties. These routine missions limit the chance for directors to detect financial anomalies. Based on the above discussion, we expect that more board meetings guarantee more time for directors to ensure financial statements' reliability. Therefore, we hypothesis the following:

Hypothesis 5. There is a negative association between EM and board activity in the Moroccan banking sector.

Audit committee

Nowadays, the audit report is one of the most critical factors influencing the financial market's opinion on a particular firm. Indeed, the famous financial crises in history were connected to fraudulent audit reports. According to Laily (2017), the audit committee's presence is necessary to safeguard shareholders' interests. If the audit committee (AC) assures effective monitoring of management actions related to financial reporting, the financial reporting quality will substantially increase. However, the influence of audit missions could be relatively low on fraud prevention in some cases (Madolidi Handoyo \& Bayunitri, 2021). For Chatterjee \& Rakshit (2020), many factors of AC such as size, independence, and meetings' frequency should be considered as essential governance mechanisms due to their impact on EM. The authors reported insignificant negative results for AC's independence and meetings. Meanwhile, the AC's size negatively affects EM among only three of the five studied sectors. The size of AC is used to measure the available resources within the committee (Lin, Li, \& Yang, 2006). Prior studies suggested that the AC's size affects its decisions (Jensen, 1993; Yermack, 1996). Indeed, a large $\mathrm{AC}$ with different resources as expertise and diversity of views is more likely to detect financial manipulation all among the reporting process (Bédard, Chtourou, \& Courteau, 2004). However, empirical research suggests that the association between AC's size and EM tends to be insignificant in several cases (Xie et al., 2003; Abbott, Parker, Peters, 2004; Soliman \& Ragab, 2013; Katmon \& Farooque, 2015). This leads to the following hypothesis:

Hypothesis 6. AC's size reduces EM in the Moroccan banking sector.

According to Lin et al., (2006), when the AC fails or lacks the required independence level, the financial reporting's quality and reliability will decrease. The more the AC's independence increases, the more it ensures better financial reporting (Beasley, Carcello, \& Hermanson, 2000). Financial authorities in Morocco encourage the establishment of an AC directed by an independent board member. Whatever the AC's composition is, the Moroccan regulation system requires independent auditors' presence. Janin \& Piot (2008) suggest that earnings quality is more accurate in firms co-audited by one of the (Big N) and an AC comprises a majority of independent directors. Similarly, several studies confirmed 
the negative association between EM practices and audit independence (Chen \& Zhang, 2012; Rajeevan \& Ajward, 2019; Ghosh et al., 2010). Thereby, we formulate the following:

Hypothesis 7. The number of independent members within the AC is associated with a minimal extent of EM in the Moroccan banking sector.

Regarding AC meetings, Xie et al., (2003) argue that an active AC reduces the extent of EM. These conclusions confirm the results of Chtourou, Bedard, \& Courteau (2001), who concluded that an active independent $\mathrm{AC}$ is negatively associated with EM practices. Also, in the USA, low AC meetings frequency is positively correlated with fraud cases (Beasley et al., 2000). Also, Lin et al., (2006) found a negative association between AC meetings number and EM's extent. Thus, our next hypothesis is as follow:

Hypothesis 8. There is a negative relationship between AC meetings and EM in the Moroccan banking sector.

\section{Ownership structure}

Agency theory argues that concentrated ownership creates issues between majority and minority shareholders, making the board's missions harder. In the Moroccan banking sector, the ownership structure is diversified. However, prior studies acknowledged many factors influencing banks' EM practices, including the ownership structure (Tran, Ly, \& Nguyen, 2020; Osemene et al., 2018; Sadjiarto, Monica, \& Budiarti, 2019). The bank owners, ranging from individuals, promoters, institutional investors, foreign or local investors, private or public investors, share a proportion of the bank's capital. Their motivation toward the bank is different. Every actor passing from managers to owners, each one has a private interest to fulfill. Although organizations with a higher proclivity for agency conflict have performant governance procedures, the ownership structure may reduce agency conflict and hence EM (Dey, 2008).

The bank's ownership structure can function as an incentive for owners to engage in ethical behavior and good practices (Sadjiarto et al., 2019). Therefore, institutional and state ownership seems to be the more influencing factors on EM practices in Moroccan banks.

Institutional ownership

Institutional ownership, specifically on a long-term basis, is considered as an essential mechanism for mitigating agency costs, reducing opportunistic management behavior, protecting investors' interests, and assisting in the convergence between managers and owners because they have the necessary incentives, voting power, and investment skills to influence managerial behavior (Jensen \& Meckling, 1976; Shleifer \& Vishny, 1986). Similarly, the significant investments made by institutional investors require them to supervise and control the company's management as closely as possible, providing them with solid monitoring incentives. In this direction, Bushee (1998) finds that institutional ownership by dedicated investors that tend to have a large and long-term investment strategy is associated with less EM. Along the same lines, Bricker \& Markarian (2015) support the view that institutional investors possess the expertise and the skill to analyze information and draw conclusions, thereby significantly reducing the managers' ability to exploit internal information to achieve their personal goals. Therefore, we propose the following hypothesis:

Hypothesis 9. Institutional ownership negatively affects EM in the Moroccan banking sector.

State ownership

Empirically in China, state ownership seems to have a good impact on earnings quality. The theoretical foundations suggest that various agency problems arise when managers are not implicated in the ownership structure because of the domination of state investors. The local banking system does not suffer from this issue. However, the situation of managers as minority shareholders with less voting rights pushes them to expropriate the banks' assets for their own benefits.

In Morocco, state ownership is primarily formed by shares owned by state entities, which are highly regulated, and their institutional quality does not differ from private companies. Thus, theoretically, 
their supervision should not allow for earnings manipulation. In emerging countries, academic research suggests that state ownership tends to restrain EM practices (Wang \& Yung, 2011; Hoang, Abeysekera, \& Ma, 2014). However, multiple studies reported a positive interplay between state ownership and the extent of EM (Firth, Fung, \& Rui, 2007; Guo \& Ma, 2015; Poli, 2015; Ben-Nasr, Boubakri, \& Cosset, 2015). Based on the above arguments and state directors' activism during board meetings in each fiscal year of our study's timeframe and their implication in the auditing mechanism, we assume that the more state ownership arises, the more EM's extent deters.

Hypothesis 10. There is a negative association between EM and state ownership.

\section{Research methodology \\ Sample selection}

The data used to conduct this study is collected manually from financial reports, ESG documents, annual reports, and financial statements of all the six listed banks in the Casablanca Stock Exchange from 2017 to 2020. Our sample comprises three international banks, ATW, BCP, and BOA, which are well implemented in the African region. The main limitation of our panel data is the timeframe; we were forced to restrain the collection process because of some missing information on auditing parameters before 2016. All the collected data were double-checked for transposition errors. After verifying the validity of our panel, we finally filtered the data to ensure the panel's homogeneity.

\section{Discretionary loan loss provision estimation}

In the banking industry, EM practices arise from loan loss provision manipulations because they are the major accruals due to their direct connection with the bank's regulatory capital. As stated by St-Hilaire \& Boisselier (2018), LLP research is crucial in the African region because of the direct effect of LLP on decision-making.

This first stage of our analysis serves to measure the EM proxy. Generally, LLPs are divided into two components, discretionary LLP (DLLP) and non-discretionary LLP (NDLLP) (Ben Othman \& Mersni, 2014). The second component seeks to cover the anticipated loss in the bank's loan portfolio or nonperforming loans due to business cycles and changes. While the first represents the part of total accruals engaged by changes in bank business conditions and accounting manipulations to change in earnings volume. According to Ben Othman \& Mersni (2014), the only way to estimate NDLLP is through the variables reflecting the level of loss in a bank's loan portfolio.

Following the approach used by Kanagaretnam, Lobo, \& Mathieu (2004), Kwak, Lee, \& Eldridge (2009), Taktak et al., (2010), and Ben Othman et Mersni (2014), which consist of estimating the DLLP level by using the one-year lagged level of non-performing loans, or the begging balance of NPL in a fiscal year, annual changes in NPL and total loans' volume. The logic behind this prediction is using LLP as a dependent variable and NDLLP characteristics as independent variables to detect the DLLP.

$$
\mathbf{L L P}=\mathbf{N D L L P}+\mathbf{D L L P} \quad(\text { Eq.1) }
$$

Therefore, $\quad \mathbf{L L P}_{\mathrm{it}}=\boldsymbol{\beta}_{\mathbf{0}}+\boldsymbol{\beta}_{1} \mathbf{N P L}_{\mathrm{it}-1}+\boldsymbol{\beta}_{2} \Delta \mathbf{N P L}_{\mathrm{it}}+\boldsymbol{\beta}_{3} \Delta \mathrm{TL}_{\mathrm{it}}+\varepsilon_{\mathrm{it}}$

Where $\left(\varepsilon_{\mathrm{it}}\right)$ is the estimated error or the DLLP. It is noteworthy that all the variables in the second equation were divided by the total loans of the previous year as a scaler to manage heteroscedasticity among our panel data.

The following tables present regression results of DLLP estimation and summary descriptive statistics of banks' loan portfolios. 
Table 1. Descriptive statistics of banks' loan portfolio

\begin{tabular}{ccccc}
\hline Variable & Mean & Std.Dev. & Min & Max \\
\hline Loan Loss Reserves & 1630.6 & 1541.633 & 58.13 & 6129.12 \\
Total Loans & 139000 & 102000 & 36726.38 & 327000 \\
Non-Performing Loans & 6159.86 & 3949.263 & 1236 & 15091.09 \\
Loans Loss Provisions & 4234.084 & 2837.336 & 550.783 & 10327.48 \\
\hline
\end{tabular}

Table 2. LLP estimation results

\begin{tabular}{|c|c|c|c|c|c|c|c|}
\hline $\operatorname{LLP}_{\text {it }}$ & Coef. & St.Err. & t-value & $\mathrm{p}$-value & $\begin{array}{l}{[95 \%} \\
\text { Conf }\end{array}$ & Interval] & Sig \\
\hline $\mathrm{NPL}_{\mathrm{it}-1}$ & 0.870 & 0.045 & 19.19 & 0.000 & 0.775 & 0.964 & $* * *$ \\
\hline$\Delta \mathrm{NPL}_{\mathrm{it}}$ & -0.553 & 0.170 & -3.25 & 0.004 & -0.908 & -0.198 & $* * *$ \\
\hline$\Delta \mathrm{TL}_{\mathrm{it}}$ & -0.048 & 0.019 & -2.50 & 0.021 & -0.088 & -0.008 & $* *$ \\
\hline Constant & -0.007 & 0.002 & -2.85 & 0.010 & -0.012 & -0.002 & $* *$ \\
\hline \multicolumn{2}{|c|}{ Mean dependent var } & 0.036 & \multicolumn{3}{|c|}{ SD dependent var } & 0.020 & \\
\hline \multicolumn{2}{|c|}{ R-squared } & 0.950 & \multicolumn{3}{|c|}{ Number of obs } & 24.000 & \\
\hline \multicolumn{2}{|c|}{ F-test } & 126.956 & \multicolumn{3}{|c|}{ Prob $>F$} & 0.000 & \\
\hline \multicolumn{2}{|c|}{ Akaike crit. (AIC) } & -184.942 & \multicolumn{3}{|c|}{ Bayesian crit. (BIC) } & -180.229 & \\
\hline
\end{tabular}

On average, in Moroccan-listed banks, LLP and NPL present $3.046 \%$ and $4.43 \%$ of total loans. Our findings are almost consistent with those of Ozili (2018). The mean of residuals in the second equation or DLLP was 0 with a maximum of 0.0764 and a minimum of -0.0068 . However, the minimal value of the absolute value of DLLP is 0.0001129 .

Generally, EM practices are relatively moderated in the Moroccan banking context due to the nonsignificance of the DLLP mean, which is equal to $0,37 \%$, contradicting the findings of Salem, Usman, \& Ezeani (2021), who suggest that the EM level is around 8\% in Islamic banks and 12\% in conventional banks in the MENA region.

\section{Model design}

To investigate the relationship between the extent of EM and corporate governance mechanisms, we estimate the following model using the GMM EGLS method, highly recommended by $\underline{\text { Shao (2019) }}$ and El Idrissi \& Alami (2021), to avoid heteroscedasticity and endogeneity problems:

$$
\begin{gathered}
\text { EM_ABS }_{i, t}=\alpha_{0}+\beta_{1} \text { SIZE }+\beta_{2} \text { INDP }+\beta_{3} \text { DUALITY }+\beta_{4} \text { GENDER }+\beta_{5} \text { AUDIT }+ \\
\beta_{6} \text { INDP_AUDIT }+\beta_{7} \text { M_AUDIT }+\beta_{8} \text { MEETINGS }+\beta_{9} \text { INST }+\beta_{10} \text { STATE }+\mu_{i}+v_{t}+\varepsilon_{i, t}
\end{gathered}
$$

Table 3. Variable description

$$
\text { (Eq.3) }
$$

\begin{tabular}{ll}
\hline \multicolumn{1}{c}{ Variable } & \multicolumn{1}{c}{ Description } \\
\hline SIZE & The total number of directors on the board. \\
\hline INDP & The proportion of independent directors to the total number of directors on the board. \\
\hline DUALITY & $\begin{array}{l}\text { A dummy variable equal to } 1 \text { when the CEO is the board chairperson and } 0 \\
\text { otherwise. }\end{array}$ \\
\hline GENDER & The number of female directors. \\
\hline AUDIT & The total number of directors in the AC. \\
\hline INDP_AUDI & The number of independent directors in the AC. \\
T & \\
\hline M_AUDIT & The total number of meetings held by the AC during a year. \\
\hline MEETINGS & The total number of meetings held by the board during a year. \\
\hline INST & The proportion of shares held by institutional investors. \\
\hline STATE & The proportion of shares held by state organizations. \\
\hline
\end{tabular}




\section{Research findings and discussion}

The second step of our estimation process consists of predicting the impact of the variables discussed in the literature review section on EM extent in listed Moroccan banks. The following tables present the correlation matrix and the descriptive statistics of all the explanatory variables used to conduct this research.

Table 4. Correlation matrix

\begin{tabular}{|c|c|c|c|c|c|c|c|c|c|c|c|}
\hline & (1) & (2) & (3) & (4) & (5) & (6) & (7) & (8) & (9) & (10) & (11) \\
\hline SIZE (1) & 1 & & & & & & & & & & \\
\hline INDP (2) & $0.455^{*}$ & 1 & & & & & & & & & \\
\hline DUALITY (3) & 0.0579 & 0.289 & 1 & & & & & & & & \\
\hline GENDER (4) & 0.0167 & 0.0698 & $-0.504^{*}$ & 1 & & & & & & & \\
\hline AUDIT (5) & $0.583^{* *}$ & $0.609^{* *}$ & $0.477^{*}$ & -0.333 & 1 & & & & & & \\
\hline $\begin{array}{l}\text { INDP_AUDIT } \\
\text { (6) }\end{array}$ & $0.424^{*}$ & $0.627^{* *}$ & 0.167 & -0.0614 & $\begin{array}{c}0.680^{* * *} \\
*\end{array}$ & 1 & & & & & \\
\hline M_AUDIT (7) & -0.147 & -0.268 & 0.333 & $-0.453^{*}$ & -0.131 & -0.352 & 1 & & & & \\
\hline $\begin{array}{l}\text { MEETINGS } \\
\text { (8) }\end{array}$ & -0.157 & -0.0776 & $0.610^{* *}$ & $\overline{-}^{-}$ & 0.229 & -0.251 & 0.404 & 1 & & & \\
\hline INST (9) & -0.350 & -0.332 & $\overline{-}^{-}$ & 0.203 & -0.343 & -0.127 & -0.353 & $\overline{-} . \overline{274}$ & 1 & & \\
\hline $\begin{array}{l}\text { STATE (10) } \\
\text { EM_ABS (11) }\end{array}$ & $\begin{array}{l}-0.110 \\
0.0641\end{array}$ & $\begin{array}{c}0.253 \\
0.0477\end{array}$ & $\begin{array}{l}0.592^{* *} \\
0.0346\end{array}$ & $\begin{array}{l}0.0492 \\
0.417^{*}\end{array}$ & $\begin{array}{c}0.254 \\
-0.0634\end{array}$ & $\begin{array}{l}0.0445 \\
-0.304\end{array}$ & $\begin{array}{c}0.0185 \\
-0.00384\end{array}$ & $\begin{array}{l}0.184 \\
0.172\end{array}$ & $\begin{array}{l}-0.507^{*} \\
-0.0876\end{array}$ & $\begin{array}{c}1 \\
0.260\end{array}$ & 1 \\
\hline
\end{tabular}

Table 5. Analysis's descriptive statics and multicollinearity results

\begin{tabular}{cccccc}
\hline Variable & Mean & Std.Dev. & Min & Max & VIF \\
\hline SIZE & 11.5 & 1.56 & 9 & 14 & 3.13 \\
INDP & .235 & .071 & .1 & .333 & 2.28 \\
DUALITY & .667 & .482 & 0 & 1 & 4.25 \\
GENDER & .17 & .12 & 0 & .333 & 2.63 \\
AUDIT & 4.208 & .884 & 3 & 6 & 7.53 \\
INDP_AUDIT & 1.458 & 1.062 & 0 & 4 & 5.33 \\
M_AUDIT & 4.958 & 1.805 & 4 & 10 & 1.94 \\
MEETINGS & 5.75 & 1.775 & 4 & 10 & 3.23 \\
INST & .839 & .035 & .798 & .92 & 2.78 \\
STATE & .196 & .239 & 0 & .708 & 3.54 \\
EM & 0 & .004 & -.007 & .008 & - \\
EM_ABS & .004 & .002 & 0 & .008 & - \\
\hline
\end{tabular}

As reported in the previous tables, there is no high correlation between explanatory variables. Also, the VIF test indicates that there are no multicollinearity issues among our panel data. With an average board size of 12 members in compliance with the regulatory requirements. Similarly, board independence is quite significant, with a maximum of $33 \%$ of board overall size and a mean of 23,5 percent. This high level of board independence affects the AC's independence which is up to $33 \%$ of this committee's size. However, board and $\mathrm{AC}$ meetings are around five reunions per fiscal year. It is noteworthy that gender diversity in the financial industry in Morocco has great potential, especially in recent years, with a mean (maximum) of 17\% (33\%) between 2017 and 2020.

Regarding the ownership structure, the financial performance of the Moroccan banking sector depends highly on the institutional development and institutional investors' implication in governance matters. Therefore, theoretically, their presence is positively correlated with performance. Additionally, state ownership is seen as a signal of performance by financial markets. In the six studied banks, state ownership is up on average to $19.6 \%$, which is a good level for such independent organizations.

The following table presents our empirical findings. For the regression specification in the four models below, our dependent variable is measured by DLLP, which is a proxy for the discretionary component of LLP.

Contrary to what we have expected, the board size reduces the level of earnings manipulations. This outcome supports the argument that greater board size is able to detect financial manipulations, and 
therefore, detect EM because larger boards are expected to ensure more expertise, knowledge, and monitoring abilities (Debnath, 2019). Therefore, we accept our first hypothesis, and we admit that banks' board size could be considered as a monitoring device to limit managers' LLP manipulations.

Similarly, we reject the model's third hypothesis because the board's independence could not reduce earnings manipulation in the studied banks. This means that independent directors are not effective in monitoring the financial reporting process, and therefore, they cannot control the managers' discretionary reporting practices. Our results confirm those of Debnath (2019), Wang (2007), and Sarkar, Sarkar, \& Sen (2008). It seems that the independent directors recruited by Moroccan banks do not enhance the overall experience rate of the board, contradicting Kapoor's \& Goel's (2019) results. However, affiliated independent directors within the AC restrict earnings manipulations due to their financial background and supervising experiences. As expected, the restricting power of $\mathrm{AC}$ is significant, especially regarding EM practices. Our findings confirm those of Siagian \& Tresnaningsih (2011). We can explain this empirical evidence by referring to the Moroccan authorities' efforts in regulating the local governance systems, which forces banks to recruit independent directors as AC's heads, providing better support in financial matters to the board and making the AC more independent from management, leading to more effective monitoring (Carcello, 2009). Moreover, Siagian \& Tresnaningsih (2011) found that an independent AC increases its oversight function without any influence from top management. Thus, we accept our seventh hypothesis.

Table 6. Regression results

\begin{tabular}{|c|c|c|c|c|c|c|}
\hline & OLS & Fixed effects & $\begin{array}{c}\text { Random } \\
\text { effects }\end{array}$ & GMM EGLS & Sign & Predicted sign \\
\hline SIZE & $\begin{array}{c}0.000483 \\
(0.319)\end{array}$ & $\begin{array}{c}0.00146 \\
(0.123)\end{array}$ & $\begin{array}{c}0.000483 \\
(0.300)\end{array}$ & $\begin{array}{c}-0.001276^{* *} \\
(-3.632)\end{array}$ & - & - \\
\hline INDP & $\begin{array}{c}0.00312 \\
(0.727)\end{array}$ & $\begin{array}{c}-0.00805 \\
(0.399)\end{array}$ & $\begin{array}{c}0.00312 \\
(0.721)\end{array}$ & $\begin{array}{l}0.021355^{* *} \\
\quad(3.228)\end{array}$ & + & - \\
\hline DUALITY & $\begin{array}{c}-0.000464 \\
(0.796)\end{array}$ & $\begin{array}{l}0 \\
(.)\end{array}$ & $\begin{array}{c}-0.000464 \\
(0.792)\end{array}$ & $\begin{array}{l}0.00902 * * * \\
(4.956)\end{array}$ & + & + \\
\hline GENDER & $\begin{array}{c}0.0128 * * \\
(0.039)\end{array}$ & $\begin{array}{c}0.0226 * \\
(0.093)\end{array}$ & $\begin{array}{c}0.0128 * * \\
(0.021)\end{array}$ & $\begin{array}{c}-0.013828 * * \\
(2.845)\end{array}$ & - & - \\
\hline AUDIT & $\begin{array}{c}0.000140 \\
(0.915)\end{array}$ & $\begin{array}{c}0.00108 \\
(0.520)\end{array}$ & $\begin{array}{l}0.000140 \\
(0.913)\end{array}$ & $\begin{array}{c}-0.000084 \\
(-0.114)\end{array}$ & 0 & - \\
\hline INDP_AUDIT & $\begin{array}{c}-0.000526 \\
(0.566)\end{array}$ & $\begin{array}{c}-0.00343^{*} \\
(0.054)\end{array}$ & $\begin{array}{c}-0.000526 \\
(0.556)\end{array}$ & $\begin{array}{c}-0.001579 * * \\
(-2.628)\end{array}$ & - & - \\
\hline M_AUDIT & $\begin{array}{c}0.000269 \\
(0.412)\end{array}$ & $\begin{array}{c}0.0000954 \\
(0.892)\end{array}$ & $\begin{array}{c}0.000269 \\
(0.397)\end{array}$ & $\begin{array}{c}-0.0000065 \\
(-0.034)\end{array}$ & 0 & - \\
\hline MEETINGS & $\begin{array}{c}0.000728 \\
(0.104)\end{array}$ & $\begin{array}{c}0.000792^{*} \\
(0.079)\end{array}$ & $\begin{array}{c}0.000728^{*} \\
(0.081)\end{array}$ & $\begin{array}{c}0.000124 \\
(0.589)\end{array}$ & 0 & - \\
\hline INST & $\begin{array}{l}0.0136 \\
(0.502)\end{array}$ & $\begin{array}{c}-0.00553 \\
(0.827)\end{array}$ & $\begin{array}{l}0.0136 \\
(0.490)\end{array}$ & $\begin{array}{c}0.019275 \\
(1.409)\end{array}$ & 0 & - \\
\hline STATE & $\begin{array}{c}0.00280 \\
(0.404)\end{array}$ & $\begin{array}{r}-0.0269 \\
(0.631)\end{array}$ & $\begin{array}{c}0.00280 \\
(0.388)\end{array}$ & $\begin{array}{c}-0.019275^{* * *} \\
(-7.656)\end{array}$ & - & - \\
\hline Intercept & $\begin{array}{l}-0.0217 \\
(0.307) \\
\end{array}$ & $\begin{array}{c}-0.00958 \\
(0.668)\end{array}$ & $\begin{array}{l}-0.0217 \\
(0.287) \\
\end{array}$ & $\begin{array}{c}-0.005489 \\
(-0.527) \\
\end{array}$ & & \\
\hline Obs & 24 & 24 & 24 & 24 & & \\
\hline $\mathbf{R}^{2}$ & 0.545 & 0.668 & - & 0.919 & & \\
\hline adj. $R^{2}$ & 0.194 & 0.153 & - & 0.857 & & \\
\hline Normality & 2.396 & 1.847 & - & 0.984 & & \\
\hline
\end{tabular}


For our study, using the random effects coefficients is the more practical solution because the Hausman test indicates that (Chi-square (9) $=8.99 ; p=0.438$ ) highlighting the non-adequacy of the fixed effects model estimations. Nevertheless, to solve endogeneity and heteroscedasticity problems that exist all among the corporate governance research, we resorted to GMM EGLS to solve all the issues mentioned above (Wintoki, Linck, \& Netter, 2012). Normality test results and the high level of significance of regression coefficients confirm the robustness of our findings.

Overall, these findings are an actual alert to the Moroccan financial authorities to further explore the roles and missions of independent directors in CSE, in perspective, to establish an effective link between board independence and controlling EM accruals.

As expected, CEO duality seems to have a positive impact on EM extent. Our findings contradict Yasser's \& Mamun's (2015) point of view, which asserts that the dual structure enhances the financial reporting quality among other positive impacts, such as financial performance and the direction strategy's clarity level. Despite that, the classic governance structure is distinguished by the CEO's extensive knowledge and dedication (Lam \& Lee, 2008). In the Moroccan context, the board seems to be like a discreet locus to fulfill the managers' interests because the regression results indicate that duality contributes to developing EM practices. However, this high level of discretion could offer more effective strategic decisions, according to Peng, Zhang, \& Li (2007). Based on the above discussion, we accept our second hypothesis, admitting that CEO duality should be carefully interpreted in the Moroccan banking sector.

In our case, gender diversity restricts EM. Thus, we accept our fourth conceptual hypothesis. This negative effect could result from women's risk-aversion level, which is theoretically high because they worry more about the bank's spending strategy and often extract less personal advantages from the firm than men (Bliss \& Potter, 2002; Yasser, Mamun, \& Suriya, 2014; Barber \& Odean, 2001). According to Gul, Srinidhi, \& Ng (2011), and in accordance with behavioral, organizational, and psychological theories, female directors are more likely to frequently attend board meetings, take on significant monitoring roles, and hold CEOs more responsible for poor performance, which enhances the information environment. For Zalata et al., (2021), women's interference with accounting matters during board meetings encourages more financial information disclosure and, therefore, systematically reduces information asymmetry between all stakeholders, limiting the CEO's discretion and opportunism. Thus, we acknowledge that female directors play a more effective monitoring role in constraining EM extent in the Moroccan banking industry.

Regarding the impact of AC's size and meetings, our results indicate that there is no significant interaction between these AC's parameters and EM level. However, these variables reduce EM practices, but not significantly. This result is similar to Ramachandran, Ngete, Subramanian, \& Sambasivan (2015), Davidson, Goodwin-Stewart, \& Kent (2005), Ngo \& Le (2021), and Abdul Rahman $\&$ Haneem Mohamed Ali (2006). Thus, we reject the associated hypothesis to these variables.

Similar to the studies conducted by Ebrahim (2007), Kjærland, Haugdal, \& Søndergaard (2020), and Sukeecheep, Yarram, \& Al Farooque (2013), the results of the panel regression suggest a positive, though insignificant, association between board activities and EM extent. In contradiction to what we have expected, which means that empirically, the board meetings do not affect EM practices. Given these findings, we reject the model's fifth hypothesis.

Further, the regression analysis points out that institutional ownership does not help reduce EM extent, but this conclusion is not statistically significant, contradicting what we have expected. In addition, state ownership seems to have a negative impact on banks' EM. These conclusions are similar to Wang \& Yung (2011) and Hoang et al., (2014). Therefore, hypothesis number 10 is fully supported, which means that state ownership in Moroccan banks is associated with higher earnings quality.

\section{Conclusion}

The analysis carried in the scope of this study points out that board size, gender diversity, AC independence, and state ownership could help reduce the DLLP manipulations in Moroccan banks. This article displays the effects of banks' governance mechanisms on the EM practices of listed banks in the 
CSE from 2017 to 2020. Despite the maturity of the academic debate on this topic, there is a gap in the literature regarding earnings management practices in the Moroccan banking industry, particularly the impact of corporate governance. Thus, we discovered the determinants of EM constraining in this vital economic industry.

This study extends EM literature by providing a new set of evidence on the impact of CG mechanisms on the DLLP in the Moroccan context. The findings show there is a powerful effect of board size, female directors, AC's independence, and state ownership on restricting EM among the studied sample. This means that our research has empirically documented two pieces of evidence.

First, the bank's board of directors provides a resourceful controlling power on the financial reporting whereby recruiting more directors, especially if they are females. In fact, this is one of the most important implications of our research. Following the resource dependence theory, female directors play a crucial role in developing a bank's external environment using their unique characteristics such as fluid networking, socializing abilities, and reinforcing financial information disclosure's process, which guarantees the information flow's efficiency. Therefore, we highly recommend that listed banks enhance their diversity strategies, especially since the empirical studies related to the agency theory suggest that board gender diversity increases its monitoring performance.

Second, the need to enhance the auditing system's functioning seems inevitable to make its impact on EM extent significant. Since our findings suggest that AC's size and meetings negatively impact EM, recruiting more directors, especially those with diversified financial expertise, makes the AC's effect more significant.

Nevertheless, our work suffers from some methodological limitations, which can be addressed in future research. First, the relatively small sample size could affect the estimations' accuracy. Second, the AC's expertise and CEOs' personal information (such as remuneration details) are not included within our variables set. This could be the main limitation of our study because such proxies could influence significatively EM practices. Therefore, future research should examine those qualitative variables. In addition, DLLP is not the only EM accruals used in the banking industry to express EM practices. Thus, future papers should combine it with the real EM estimation to build more solid conclusions on the interplay between CG and EM, offering sensitive managerial implications and recommendations.

\section{References}

Abbott, L. J., Parker, S., \& Peters, G. F. (2004). Audit Committee Characteristics and Restatements. AUDITING: A Journal of Practice \& Theory, 23(1), 69-87.

Abdul Rahman, R., \& Haneem Mohamed Ali, F. (2006). Board, audit committee, culture and earnings management : Malaysian evidence. Managerial Auditing Journal, 21(7), 783-804.

Al Hajjar, C., Mokhtar, E., \& Mandour, M. (2021). The impact of corporate governance on earnings management in Islamic and conventional banks. BAU Journal - Society, Culture and Human Behavior, 2(2).

Al-Musali, M. A. K. M., \& Ku Ismail, K. N. I. (2015). Board diversity and intellectual capital performance. Accounting Research Journal, 28(3), 268-283.

Anderloni, L., Moro, O., \& Tanda, A. (2020). Governance and Performance in Insurance Companies: A Bibliometric Analysis and A Meta-Analysis. International Journal of Economics and Finance, 12(11).

Andries, K., Gallemore, J., \& Jacob, M. (2017). The effect of corporate taxation on bank transparency: Evidence from loan loss provisions. Journal of Accounting and Economics, 63(2-3), 307-328.

Bradbury, M., Mak, Y. T., \& Tan, S. M. (2006). Board Characteristics, Audit Committee Characteristics, and Abnormal Accruals. Pacific Accounting Review, 18(2), 47-68.

Barber, B., \& Odean, T. (2001). Boys Will Be Boys : Gender, Overconfidence, And Common Stock Investment. The Quarterly Journal of Economics, 116, 261-292.

Beasley, M. S., Carcello, J. V., Hermanson, D. R., \& Lapides, P. D. (2000). Fraudulent Financial Reporting: Consideration of Industry Traits and Corporate Governance Mechanisms. Accounting Horizons, 14(4), 441-454. 
Bédard, J., Chtourou, S. M., \& Courteau, L. (2004). The Effect of Audit Committee Expertise, Independence, and Activity on Aggressive Earnings Management. AUDITING: A Journal of Practice \& Theory, 23(2), 13-35.

Ben Othman, H., \& Mersni, H. (2014). The use of discretionary loan loss provisions by Islamic banks and conventional banks in the Middle East region: A comparative study. Studies in Economics and Finance, 31(1), 106-128.

Ben-Nasr, H., Boubakri, N., \& Cosset, J.-C. (2015). Earnings quality in privatized firms : The role of state and foreign owners. Journal of Accounting and Public Policy, 34(4), 392-416.

Bliss, R. T., \& Potter, M. (2002). Mutual fund managers: Does gender matter?, Journal of Business and Economic Studies, 8, 1-15.

BKAM. (2020). Annual report on banking supervision - 2020. Bank AL-MAGHRIB (27 July 2021).

Boussaid, N., Hamza, T., \& Sougne, D. (2015). Corporate Board Attributes And Conditional Accounting Conservatism: Evidence From French Firms. Journal of Applied Business Research, 31(3), 871.

Bricker, R., \& Markarian, G. (2015). Institutional Investors and Insider Trading Profitability. European Accounting Review, 24(3), 495-518.

Bushee, B. (1998). The Influence of Institutional Investors on Myopic R\&D Investment Behavior. The Accounting Review, 73(3), 305-333.

Carcello, J. V. (2009). Governance and the Common Good. Journal of Business Ethics, 89(S1), 11-18.

Ceccobelli, G., \& Giosi, A. (2019). Earnings management practices in the banking industry: The role of bank regulation and supervision. Corporate Governance: Search for the Advanced Practices, 193-214.

Chatterjee, R., \& Rakshit, D. (2020). Association Between Earnings Management and Corporate Governance Mechanisms : A Study Based on Select Firms in India. Global Business Review, $1-19$.

Chen, J. J., \& Zhang, H. (2012). The Impact of the Corporate Governance Code on Earnings Management - Evidence from Chinese Listed Companies: The Impact of the Corporate Governance Code on Earnings Management. European Financial Management, 20(3), 596-632.

Chtourou, S.M., Bedard, J. and Courteau, L. (2001) Corporate Governance and Earnings Management. Working Paper, Laval University, Canada.

Cornett, M. M., McNutt, J. J., \& Tehranian, H. (2006). Performance Changes Around Bank Mergers : Revenue Enhancements versus Cost Reductions. Journal of Money, Credit, and Banking, 38(4), 1013-1050.

Curcio, D., \& Hasan, I. (2015). Earnings and capital management and signaling: The use of loan-loss provisions by European banks. The European Journal of Finance, 21(1), 26-50.

Dahya, J., Garcia, L. G., \& van Bommel, J. (2009). One Man Two Hats : What's All the Commotion! Financial Review, 44(2), 179-212.

Dalton, D. R. (2012). Counterpoints to separating the roles of CEO and board chair. Corporate Board, 33(194), 16-20.

Davidson, R., Goodwin-Stewart, J., \& Kent, P. (2005). Internal governance structures and earnings management. Accounting and Finance, 45(2), 241-267.

Debnath, P. (2019). A Study on Contemporary Earnings Management and Corporate Governance Practices in India. [Doctoral dissertation, Tripura University].

Dey, A. (2008). Corporate Governance and Agency Conflicts. Journal of Accounting Research, 46(5), 1143-1181.

El Idrissi, I., \& Alami, Y. (2021). The financial impacts of board mechanisms on performance: The case of listed Moroccan banks. International Journal of Financial, Accounting, and Management, 3(2), 93-113.

Ebrahim, A. (2007). Earnings management and board activity: An additional evidence. Review of Accounting and Finance, 6(1), 42-58.

Elghuweel, M. I., Ntim, C. G., Opong, K. K., \& Avison, L. (2017). Corporate governance, Islamic governance and earnings management in Oman : A new empirical insights from a behavioural theoretical framework. Journal of Accounting in Emerging Economies, 7(2), 190-224. 
Endri, E., Marlina, A., \& Hurriyaturrohman. (2020). Impact of internal and external factors on the net interest margin of banks in Indonesia. Banks and Bank Systems, 15(4), 99-107.

Fama, E. F., \& Jensen, M. C. (1983). Separation of Ownership and Control. The Journal of Law \& Economics, 26(2), 301-325.

Fan, Y., Jiang, Y., Zhang, X., \& Zhou, Y. (2019). Women on boards and bank earnings management : From zero to hero. Journal of Banking \& Finance, 107, 105607.

Farag, H., \& Mallin, C. (2019). Monitoring corporate boards: Evidence from China. The European Journal of Finance, 25(6), 524-549.

Firth, M., Fung, P. M. Y., \& Rui, O. M. (2007). Ownership, two-tier board structure, and the informativeness of earnings - Evidence from China. Journal of Accounting and Public Policy, 26(4), 463-496.

García Lara, J. M., García Osma, B., \& Penalva, F. (2009). Accounting conservatism and corporate governance. Review of Accounting Studies, 14(1), 161-201.

Ge, W., \& Kim, J.-B. (2014). Boards, takeover protection, and real earnings management. Review of Quantitative Finance and Accounting, 43(4), 651-682.

Ghosh, A., Marra, A., \& Moon, D. (2010). Corporate Boards, Audit Committees, and Earnings Management: Pre- and Post-SOX Evidence: Corporate Boards, Audit Committees and Earnings Management. Journal of Business Finance \& Accounting, 37(9-10), 1145-1176.

Greenawalt, M. B., \& Sinkey, J. F. (1988). Bank loan-loss provisions and the income-smoothing hypothesis : An empirical analysis, 1976-1984. Journal of Financial Services Research, 1(4), 301-318.

Gul, F. A., Srinidhi, B., \& Ng, A. C. (2011). Does board gender diversity improve the informativeness of stock prices? Journal of Accounting and Economics, 51(3), 314-338.

Guo, F., \& Ma, S. (2015). Ownership Characteristics and Earnings Management in China. The Chinese Economy, 48(5), 372-395.

Hoang, T., Abeysekera, I., \& Ma, S. (2014). State ownership and earnings management: Empirical evidence from Vietnamese listed firms. Faculty of Business - Papers (Archive), 257-268.

IMF. (2019). Morocco: 2019 Article IV Consultation-Press Release; Staff Report; and Statement by the Executive Director for Morocco, Country Report No. 19/230.

Jamaludin, N. D., Sanusi, Z. M., \& Kamaluddin, A. (2015). Board Structure and Earnings Management in Malaysian Government Linked Companies. Procedia Economics and Finance, 28, 235-242.

Janin, R., \& Piot, C. (2008). L'influence des auditeurs externes et des comités d'audit sur le contenu informatif des manipulations comptables. La Revue des Sciences de Gestion, Direction et Gestion, 233, 23-33.

Jensen, M. C. (1993). The Modern Industrial Revolution, Exit, and the Failure of Internal Control Systems. The Journal of Finance, 48(3), 831-880.

Jensen, M. C., \& Meckling, W. H. (1976). Theory of the firm : Managerial behavior, agency costs, and ownership structure. Journal of Financial Economics, 3(4), 305-360.

Kanagaretnam, K., Lobo, G. J., \& Mathieu, R. (2004). Earnings Management to Reduce Earnings Variability : Evidence from Bank Loan Loss Provisions. Review of Accounting and Finance, 3(1), 128-148.

Kapoor, N., \& Goel, S. (2019). Do diligent independent directors restrain earnings management practices? Indian lessons for the global world. Asian Journal of Accounting Research, 4(1), 52 69.

Katmon, N., \& Farooque, O. A. (2015). Exploring the Impact of Internal Corporate Governance on the Relation Between Disclosure Quality and Earnings Management in the UK Listed Companies. Journal of Business Ethics, 142(2), 345-367.

Kjærland, F., Haugdal, A. T., Søndergaard, A., \& Vågslid, A. (2020). Corporate Governance and Earnings Management in a Nordic Perspective: Evidence from the Oslo Stock Exchange. Journal of Risk and Financial Management, 13(11), 256.

Klein, A. (2002). Audit committee, board of director characteristics, and earnings management. Journal of Accounting and Economics, 33(3), 375-400.

Kwak, W., Lee, H.-Y., \& Eldridge, S. W. (2009). Earnings Management by Japanese Bank Managers Using Discretionary Loan Loss Provisions. Review of Pacific Basin Financial Markets and Policies, 12(01), 1-26. 
Laily, N. (2017). The Effects of Good Corporate Governance and Audit Quality on Earnings Management. Journal of Accounting and Business Education, 1(1), 134-143.

Levine, R. (2004). The Corporate Governance of Banks - a concise discussion of concepts and evidence. No 3404, Policy Research Working Paper Series, The World Bank.

Lam, T., \& Lee, S. Kam. (2008). CEO duality and firm performance : Evidence from Hong Kong. Corporate Governance, 8, 299-316.

Lin, J. W., Li, J. F., \& Yang, J. S. (2006). The effect of audit committee performance on earnings quality. Managerial Auditing Journal, 21(9), 921-933.

Lipton, M., \& Lorsch, J. W. (1992). A Modest Proposal for Improved Corporate Governance. The Business Lawyer, 48(1), 59-77.

Lobo, G. J., \& Yang, D.-H. (2001). Bank Managers' Heterogeneous Decisions on Discretionary Loan Loss Provisions. Review of Quantitative Finance and Accounting, 16(3), 223-250.

Ma, C. K. (1988). Loan Loss Reserves and Income Smoothing: The Experience In the U.S. Banking Industry. Journal of Business Finance \& Accounting, 15(4), 487-497.

Madolidi Handoyo, B. R., \& Bayunitri, B. I. (2021). The influence of internal audit and internal control toward fraud prevention. International Journal of Financial, Accounting, and Management, $3(1), 45-64$.

Makhaiel, N., \& Sherer, M. (2017). In the name of others : An investigation of earnings management motives in Egypt. Journal of Accounting in Emerging Economies, 7(1), 61-89.

Menicucci, E. (2020). Earnings Quality: Definitions, Measures, and Financial Reporting. Springer International Publishing.

Mersni, H., \& Ben Othman, H. (2016). The impact of corporate governance mechanisms on earnings management in Islamic banks in the Middle East region. Journal of Islamic Accounting and Business Research, 7(4), 318-348.

Musah, A., \& Adutwumwaa, M. Y. (2021). The effect of corporate governance on financial performance of rural banks in Ghana. International Journal of Financial, Accounting, and Management, 2(4), 305-319.

Ngo, D. N. P., \& Le, A. T. H. (2021). Relationship Between the Audit Committee and Earning Management in Listed Companies in Vietnam. The Journal of Asian Finance, Economics, and Business, 8(2), 135-142.

Nguyen, T. H. H., Ntim, C. G., \& Malagila, J. K. (2020). Women on corporate boards and corporate financial and non-financial performance: A systematic literature review and future research agenda. International Review of Financial Analysis, 71, 101554.

Niu, F. F. (2006). Corporate governance and the quality of accounting earnings: A Canadian perspective. International Journal of Managerial Finance, 2(4), 302-327.

Nuanpradit, S. (2019). Real earnings management in Thailand : CEO duality and serviced early years. Asia-Pacific Journal of Business Administration, 11(1), 88-108.

Omri, A., \& Ajlani, I. (2008). Gouvernance des banques tunisiennes et gestion des résultats: rôle du conseil d'administration. Deuxième colloque international Fiscalité Droit Gestion (Hammamet - Mai 2008).

Osemene, O., Adeyele, J., \& Adinnu, P. (2018). The impact of the ownership structure and board characteristics on earnings management in Nigeria's listed deposit money banks. Ekonomski Horizonti, 20(3), 215-227.

Ozili, P. K. (2018). Bank loan loss provisions, investor protection, and the macroeconomy. International Journal of Emerging Markets, 13(1), 45-65.

Ozili, P. K., \& Outa, E. (2017). Bank loan loss provisions research : A review. Borsa Istanbul Review, 17(3), 144-163.

Panzer, L., \& Müller, S. (2015). Earnings quality and gender diversity on German supervisory boards : An empirical analysis. Problems and Perspectives in Management, 13(4), 9-18.

Peng, M. W., Zhang, S., \& Li, X. (2007). CEO Duality and Firm Performance during China's Institutional Transitions. Management and Organization Review, 3(2), 205-225.

Poli, S. (2015). Do Ownership Structure Characteristics Affect Italian Private Companies' Propensity to Engage in the Practices of "Earnings Minimization" and "Earnings Change Minimization"? International Journal of Economics and Finance, 7(6), 193-207. 
Priharta, A., Rahayu, D. P., Marlapa, E., \& Endri, E. (2020). The Factors Influencing Earnings Management and Implications for the Cost of Equity Capital. International Journal of Innovation, 13(8), 19.

Rajeevan, S., \& Ajward, R. (2019). Board characteristics and earnings management in Sri Lanka. Journal of Asian Business and Economic Studies, 27(1), 2-18.

Ramachandran, J., Ngete, Z. A., Subramanian, R., \& Sambasivan, M. (2015). Does corporate governance influence earnings management?: Evidence from Singapore. The Journal of Developing Areas, 49(3), 263-274.

Sadjiarto, A., Monica, C. C., \& Budiarti, W. R. (2019). Ownership Structure and Earnings Management in Indonesian Listed Banks. Journal of Economics and Business, 2(2), 261-272.

Salem, R., Usman, M., \& Ezeani, E. (2021). Loan loss provisions and audit quality : Evidence from MENA Islamic and conventional banks. The Quarterly Review of Economics and Finance, 79, 345-359.

Salem, S. B., Labidi, M., \& Mansour, N. (2020). Empirical evidence on Non-Performing Loans and credit frictions: banking sector in Tunisia. International Journal of Financial, Accounting, and Management, 2(3), 171-183.

Sarkar, J., Sarkar, S., \& Sen, K. (2008). Board of Directors and Opportunistic Earnings Management : Evidence from India. Journal of Accounting, Auditing \& Finance, 23(4), 517-551.

Saurina, J. (2009). Loan loss provisions in Spain. A working macroprudential tool. Revista de Estabilidad Financiera, 17, 11-26.

Shao, L. (2019). Dynamic study of corporate governance structure and firm performance in China: Evidence from 2001-2015. Chinese Management Studies, 13(2), 299-317.

Shleifer, A., \& Vishny, R. W. (1986). Greenmail, White Knights, and Shareholders' Interest. The RAND Journal of Economics, 17(3), 293-309.

Strydom, M., Au Yong, H. H., \& Rankin, M. (2016). A few good (wo)men? Gender diversity on Australian boards. Australian Journal of Management, 42(3), 404-427.

Siagian, F. T., \& Tresnaningsih, E. (2011). The impact of independent directors and independent audit committees on earnings quality reported by Indonesian firms. Asian Review of Accounting, 19(3), 192-207.

Schipper, K., (1989). Commentary on earnings management. Accounting Horizons 3, 91-102.

Soliman, M., \& Ragab, A. A. (2013). Audit Committee Effectiveness, Audit Quality, and Earnings Management : An Empirical Study of the Listed Companies in Egypt. SSRN Electronic Journal.

Srinidhi, B., Gul, F. A., \& Tsui, J. (2011). Female Directors and Earnings Quality*. Contemporary Accounting Research, 28(5), 1610-1644.

St-Hilaire, W. A., \& Boisselier, P. (2018). Evaluating profitability strategies and the determinants of the risk performance of sectoral and banking institutions. Journal of Economic and Administrative Sciences, 34(3), 174-186.

Sugianto, S., Oemar, F., Hakim, L., \& Endri, E. (2020). Determinants of Firm Value in the Banking Sector: Random Effects Model. International Journal of Innovation, 12(8), 11.

Sukeecheep, S., Yarram, S. R., \& Al Farooque, O. (2013). Earnings management and board characteristics in Thai Listed Companies. The 2013 IBEA, International Conference on Business, Economics, and Accounting.

Taktak, N. B., \& Mbarki, I. (2014). Board characteristics, external auditing quality, and earnings management: Evidence from the Tunisian banks. Journal of Accounting in Emerging Economies, 4(1), 79-96.

Taktak, N. B., Shabou, R., \& Dumontier, P. (2010). Income Smoothing Practices : Evidence from Banks Operating in OECD Countries. International Journal of Economics and Finance, 2(4), 140150.

Tran, T. Q., Ly, A. H., \& Nguyen, D. K. N. (2020). Relationship between Ownership Structures and Earnings Management Behavior in Vietnamese Commercial Banks. The Journal of Asian Finance, Economics, and Business, 7(9), 401-407.

Tricker, R. I. (1994). International corporate governance: Text, readings, and cases. Prentice Hall.

Vafeas, N. (1999). Board meeting frequency and firm performance. Journal of Financial Economics, 53(1), 113-142. 
Vasilakopoulos, K., Tzovas, C., \& Ballas, A. (2018). The impact of corporate governance mechanisms on EU banks' income smoothing behavior. Corporate Governance: The International Journal of Business in Society, 18(5), 931-953.

Wang, B. (2007). Do independent directors play role : Perspective from the earnings quality of Chinese listing firms. Research of Finance, 1(1), 109-201.

Wang, L., \& Yung, K. (2011). Do State Enterprises Manage Earnings More than Privately Owned Firms? The Case of China: do state enterprises manage earnings? Journal of Business Finance \& Accounting, 38(7-8), 794-812.

Wintoki, M. B., Linck, J. S., \& Netter, J. M. (2012). Endogeneity and the dynamics of internal corporate governance. Journal of Financial Economics, 105(3), 581-606.

Xie, B., Davidson, W. N., \& DaDalt, P. J. (2003). Earnings management and corporate governance: The role of the board and the audit committee. Journal of Corporate Finance, 9(3), 295-316.

Yasser, Q. R., \& Mamun, A. A. (2015). The impact of CEO duality attributes on earnings management in the East. Corporate Governance, 15(5), 706-718.

Yasser, Q. R., Mamun, A. A., \& Suriya, A. (2014). CEO duality structure and firm performance in Pakistan. Faculty of Business - Papers (Archive), 57-69.

Yermack, D. (1996). Higher market valuation of companies with a small board of directors. Journal of Financial Economics, 40(2), 185-211.

Zalata, A. M., Ntim, C. G., Alsohagy, M. H., \& Malagila, J. (2021). Gender diversity and earnings management: The case of female directors with financial background. Review of Quantitative Finance and Accounting.

Zgarni, A., \& Fedhila, H. (2019). Discretionary Loan Loss Provisions, Earnings Management and Capital Management in Banks. Asian Social Science, 15(7), 144-152. 